\title{
ASSESSMENT OF MILK PRODUCTION AND QUALITY IN SOHAGI EWES AT DIFFERENT PARITIES AND LACTATION STAGES UNDER INTENSIVE FARMING SYSTEMS
}

\author{
M. Y. Elaref*(1), A. Elnahas ${ }^{(1)}$ and M. M. Ali(2) \\ (1) Department of Animal Production, Faculty of Agriculture, Sohag University, Sohag, Egypt \\ (2) Department of Animal Production, Faculty of Agriculture, Menoufia University, Shebein Elkom, \\ Egypt \\ *Corresponding author: mohammed.youssef@agr.sohag.edu.eg - Phone: 01004503825
}

Received: Sep. 8, 2021

Accepted: Oct. 5, 2021

\begin{abstract}
This study was conducted to assess milk production and quality in Sohagi ewes at different parities and lactation stages under intensive farming systems. Forty single-born Sohagi ewes (8 ewes / each parity, from $1^{\text {st }}$ to $5^{\text {th }}$ ) were used, daily ration of ewes consisted of $60 \%$ concentrate mixture and $40 \%$ Egyptian clover and wheat straw as roughage, diets were offered to the ewes to meet their daily requirements. Milk yield, fat corrected milk (FCM6.5\%), and milk components (fat, protein, lactose, total solids, solids not fat and ash) were recorded and estimates weekly for 15 weeks of lactation. Results revealed that the lactation stage had significant $(P<0.05)$ effects on daily milk yield, FCM6.5\%, and fat, protein, SNF, and total solids contents, mid-lactation had the highest value (1051.6 and $984.3 \mathrm{ml} / \mathrm{d})$ followed by early- lactation $(986.1$ and $944.5 \mathrm{ml} / \mathrm{d})$ and latelactation had the lowest values $(730$ and $702.7 \mathrm{ml} / \mathrm{d})$. Milk fat, protein, SNF, and total solids were higher $(P<0.05)$ at early- and late-lactation than at mid-lactation. Daily milk yield, FCM6.5\%, and fat, protein, SNF, and total solids contents were increased significantly (p $<0.05$ ) with advancing in parity number of ewes until $4^{\text {th }}$ parity, then decreasing at $5^{\text {th }}$ parity. A significant $(P<0.01)$ and positive correlations were found between the parity number and daily milk yield, FCM6.5\% and milk contents of fat, protein, SNF and total solids. Finally, the milk production and quality of Sohagi ewes of higher parities have improved, and their use under intensive farm systems will improve the incomes of the breeders. Also, Sohagi ewes have a potential ability to produce milk, which is suitable for dairy products manufacture, which may represent a modern approach to improve the value chain for dairy processing in Upper Egypt, which often depends on milk from cows and buffaloes.
\end{abstract}

Keys word: Sohagi ewes, parity, lactation stage, milk yield, milk composition.

\section{INTRODUCTION}

In the past few years, interest in milk produced from small ruminants has increased to find new ways to exploit the potential of local strains, and now dairy products from small ruminants are looking for new consumer markets (Selvaggi et al., 2014). Although dairy products from small ruminants are healthy and preferred for patients with cardiovascular disease, cancer, obesity, and diabetes as they are rich in essential fatty acids, few studies have been conducted on the manufacture of dairy products from small ruminants milk
(Markiewicz-Keszycka et al., 2013). In Egypt, sheep are the most abundant ruminant livestock species, and a great opportunity exists to enhance their productivity because of their suitability to the different agricultural conditions in the country, especially in the reclaimed and desert lands (Elshazly and Youngs, 2019). Sheep milk is less used on a large scale in the dairy industry in Egypt, where Egyptian sheep breeds are not considered as dairy animals with low genetic value (FAO, 2004), it produces only 92,478 tons of milk yearly (FAOSTAT, 2019). Many previous publications have estimated milk yield and its components 
from some of these breeds, such as Rahmani ewes (Abd Allah et al., 2011; Hassan et al., 2018); Ossimi ewes (EIMalky et al., 2019; Ebeid et al., 2019); Barki ewes (El-Bassiony, 2016; Abd El Tawab et al., 2020). Under intensive farming systems, some Egyptian sheep breeds are distinguished by their medium milk production with good properties that help their newborn lambs to survive and grow well during the lactation period and before weaning. Elaref et al. (2020) reported that Sohagi ewes produce about 68-82 $L$ of milk during the first $\mathbf{1 0 5}$ days of lactation. Factors affecting milk yield and milk composition of Sohagi ewes were not previously studied by researchers. Therefore, understanding these factors may improve milk production and maximize profits, where lower milk production leads to lower growth rates of offspring during the suckling period. Aiming to recognize the potential milk ability of Sohagi ewes, this study was designed to assess milk production and quality in Sohagi ewes at different parities and lactation stages under intensive farming systems.

\section{MATERIALS AND METHODS}

The Federation of Animal Science Societies guidelines provisions "Care and Use of Agricultural Animals in Research and Teaching" - 3rd Edition, Champaign,
Illinois, were considered during the experiment.

\section{Animal and management conditions}

Healthy Forty single-born Sohagi ewes of different parities (8 ewes I each parity from $1^{\text {st }}$ to $5^{\text {th }}$ ) were used at the experimental sheep farm of the animal production department, Faculty of Agriculture, Sohag University, El-kawthar city, Sohag, Egypt. Sohag is one of the rural governorates in Upper Egypt (latitude $26.36^{\circ}$, longitude $31.38^{\circ}$ and elevation above sea level $68.70 \mathrm{~m}$ ), characterized by a desert climate, where the temperature is high in summer and moderate in winter, the average yearly maximum and minimum temperature of Sohag is $30.4^{\circ} \mathrm{C}$, and $17.0^{\circ} \mathrm{C}$, respectively (Ouda and Zohry, 2016). The daily feed ration of ewes consisted of $60 \%$ concentrate mixture and $40 \%$ Egyptian clover (Trifolium alexandrinum) and wheat straw as roughage. Diets were offered to the ewes to meet their daily requirements, according to NRC (2007). The chemical analysis of the experimental ingredients is shown in Table 1. The lambing season lasted from mid of November to the end of December. After lambing, ewes were housed in shaded barns with rice straw as a bedding material with a fixed drinking trough, and freshwater was available throughout the day.

Table 1: Chemical composition of ingredients (\% DM basis) used in experimental rations.

\begin{tabular}{lccc}
\hline & \multicolumn{3}{c}{ Ingredient of daily feed ration } \\
\cline { 2 - 4 } & Concentrate mixture & Egyptian clover & Wheat straw \\
\hline Dry matter & 89.76 & 15.31 & 88.63 \\
Organic matter & 88.34 & 86.72 & 87.91 \\
Crude protein & 15.61 & 15.79 & 3.18 \\
Crude fiber & 13.26 & 21.64 & 38.14 \\
Ether extract & 3.68 & 1.73 & 1.27 \\
Nitrogen free extract ${ }^{2}$ & 55.79 & 47.56 & 45.32 \\
\hline${ }^{1}$ Concentrate mixture composed of $50 \%$ yellow maize, $35 \%$ wheat barn, 12\% soybean meal, 2\% \\
limestone, and 1\% common salt. \\
${ }^{2}$ Nitrogen free extract calculated by the difference.
\end{tabular}




\section{Milk production and composition}

Milk yield and fat corrected milk (FCM6.5 \%) of all individual ewes were recorded (morning at 7:00 a.m. and evening at 5:00 p.m.) once a week throughout the lactation period (15 weeks) using the kid suckling technique during the suckling period and then by hand milking from weaning until the end of the experiment. Representative milk samples about $(50 \mathrm{~mL}$ ) were obtained once a week from both halves of the udder in the morning and evening on the same day. Samples were combined per ewe and analyzed for total solids (TS), fat, protein, lactose, solids not fat (SNF), and ash by using an automatic milk analyzer (Lactoscan MCC, Lactoscan milktronic). Daily milk yield, FCM6.5 \% = milk yield $(0.37+0.097$ fat $\%)$, and total milk yield were calculated according to Pulina and Nudda (2004).

\section{Statistical analysis}

The statistical analyses were performed using the PROC MIXED of SAS (SAS 9.3, SAS Inst. Inc., Cary, NC) with repeated measurements. The statistical mixed model included the fixed effects of parity number of the ewe $\left(1^{\text {st }}, 2^{\text {nd }}, 3^{\text {rd }}, 4^{\text {th }}\right.$, $5^{\text {th }}$ ), lactation stage (Early: from $1^{\text {st }}$ to $3^{\text {rd }}$ week, Mid: from $4^{\text {th }}$ to $9^{\text {th }}$ week, Late: from $10^{\text {th }}$ to $15^{\text {th }}$ week), the random effect of animal, the interactions (parity number of the ewe with lactation stage) and the residual error. Differences between LSM were determined with the PDIFF option of SAS. Statistical model used to analyze the data was:

$Y_{i j k}=\mu+P_{i}+L S_{j}+(P \times L S)_{i j}+A_{k}+\varepsilon_{i j k l}$

Where $Y_{i j k}$ is the dependent variable, $\mu$ is the overall mean, $P_{i}$ is the fixed effect of parity number of the ewe $\left(1^{\text {st }}, 2^{\text {nd }}, 3^{\text {rd }}, 4^{\text {th }}\right.$, $\left.5^{\text {th }}\right), L S_{j}$ the fixed effect of lactation stage (Early-, Mid-, Late-lactation), (P× LS $)_{i j}$ the interaction between parity number of the ewe and lactation stage, $A_{k}$ the random effect of animal and $\varepsilon_{i j k l}$ is the random residual error.

\section{RESULTS AND DISCUSSION}

\section{Lactation curve behavior}

Over the lactation period of 15 weeks, the lactation curve behavior was the same in all studied parities, but milk yield of ewes in the $4^{\text {th }}$ parity is higher than those of ewes in the $3^{\text {rd }}$ and $5^{\text {th }}$ parities during the entire length of lactation, and milk yield of ewes in the $1^{\text {st }}$ and $2^{\text {nd }}$ parities was the lowest $(P<0.05)$ compared to that of ewes in the above parities (Fig. 1). Moreover, the lactation stage had a significant effect $(P<0.05)$ on the lactation curve behavior_of Sohagi ewes. Milk yield increased from the $1^{\text {st }}$ week and reached the peak at the $3^{\text {rd }}$ week of lactation (earlylactation, from $1^{\text {st }}$ to $3^{\text {rd }}$ week), persisting until the $9^{\text {th }}$ week (mid-lactation, from $4^{\text {th }}$ to $9^{\text {th }}$ week) when a significant liner drop in the milk yield occurred and continued until the $15^{\text {th }}$ week of lactation (latelactation, from $10^{\text {th }}$ to $15^{\text {th }}$ week).

This result was in line with Adegoke et al. (2017), who reported that milk yield of West African dwarf ewes is at a maximum during the $3^{\text {rd }}$ week of lactation and then falls steadily until the $12^{\text {th }}$ week of lactation in the $1^{\text {st }}, 2^{\text {nd }}$, and $3^{\text {rd }}$ parities. Also, Kuchtík et al. (2017) found that the peak of milk yield of Lacaune ewes occurred in the early lactation and then gradually decreased, which could be related to lactation advancement and changes in pasture quality during the study. Hassan et al. (2018) found that the peak of milk production of Rahmani and Chios ewes was recorded in the $5^{\text {th }}$ week of lactation, and then it began to decline in milk production until the $15^{\text {th }}$ week of the lactation period. Adegoke et al. (2017) suggested that this pattern could be due to the fact that the body and mammary gland of young animals are still developing during the first part of lactation. In general, Cappio-Borlino et al. 


\section{Y. Elaref, et al.,}

(1997) and Pulina et al. (2005) reported that the milk yield of dairy ewes during the entire length of lactation, in the third parity is higher than those of ewes in the first and second parities.

\section{Milk production and quality}

Daily milk yield, fat corrected milk (FCM $6.5 \%$ ), and total milk yield were increased $(P<0.05)$ with advancing parity number until the $4^{\text {th }}$ parity and then began to decline from the $5^{\text {th }}$ parity. Highest values $(P<0.05)$ were noted for $4^{\text {th }}$ parity, followed by $3^{\text {rd }}$ and $5^{\text {th }}$ parities, while the lowest values $(P<0.05)$ were observed for $1^{\text {st }}$ and $2^{\text {nd }}$ parities. Total milk yield was improved by $10.29 \%$ in $2^{\text {nd }}$ lactation than $1^{\text {st }}$ lactation, $6.83 \%$ in $3^{\text {rd }}$ lactation than $2^{\text {nd }}$ lactation, and $1.64 \%$ in $4^{\text {th }}$ lactation than $3^{\text {rd }}$ lactation and then began to decline during the $5^{\text {th }}$ lactation by $4 \%$ compared to the $4^{\text {th }}$ lactation (Table 2 and Fig. 2).

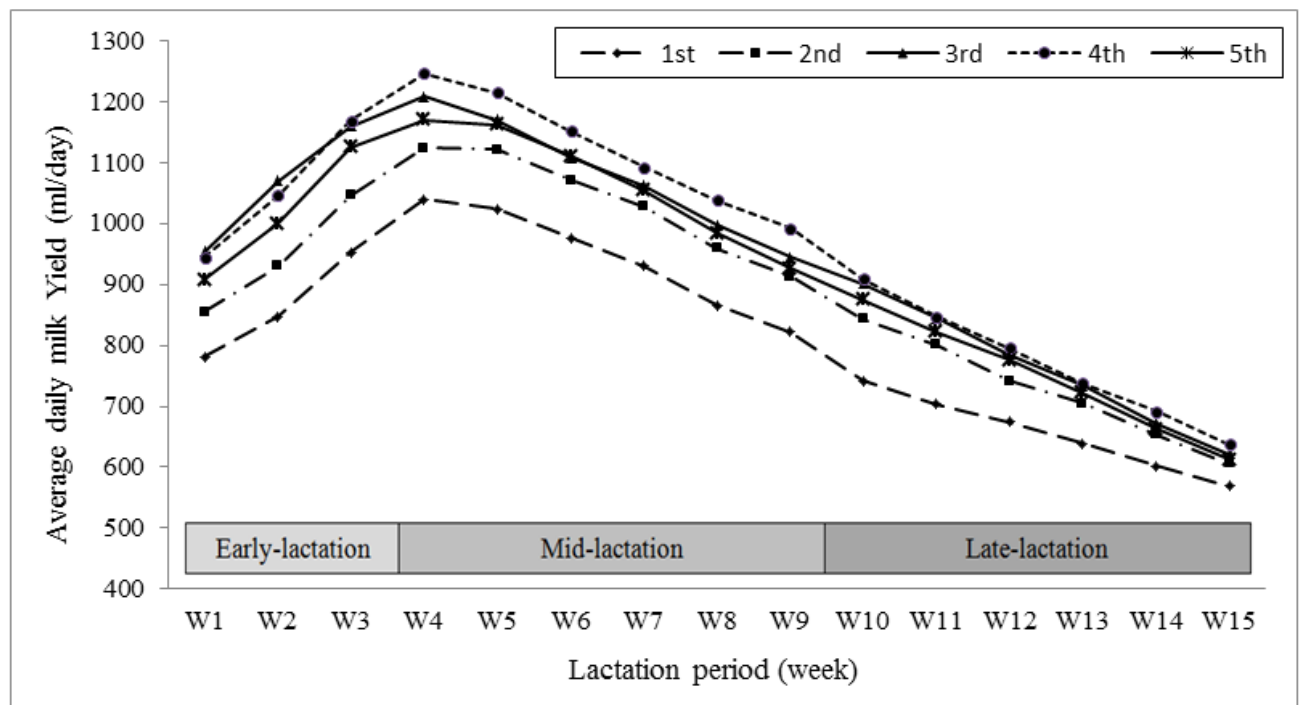

Figure 1. Lactation curve of Sohagi ewes as affected by parity number and lactation stage.

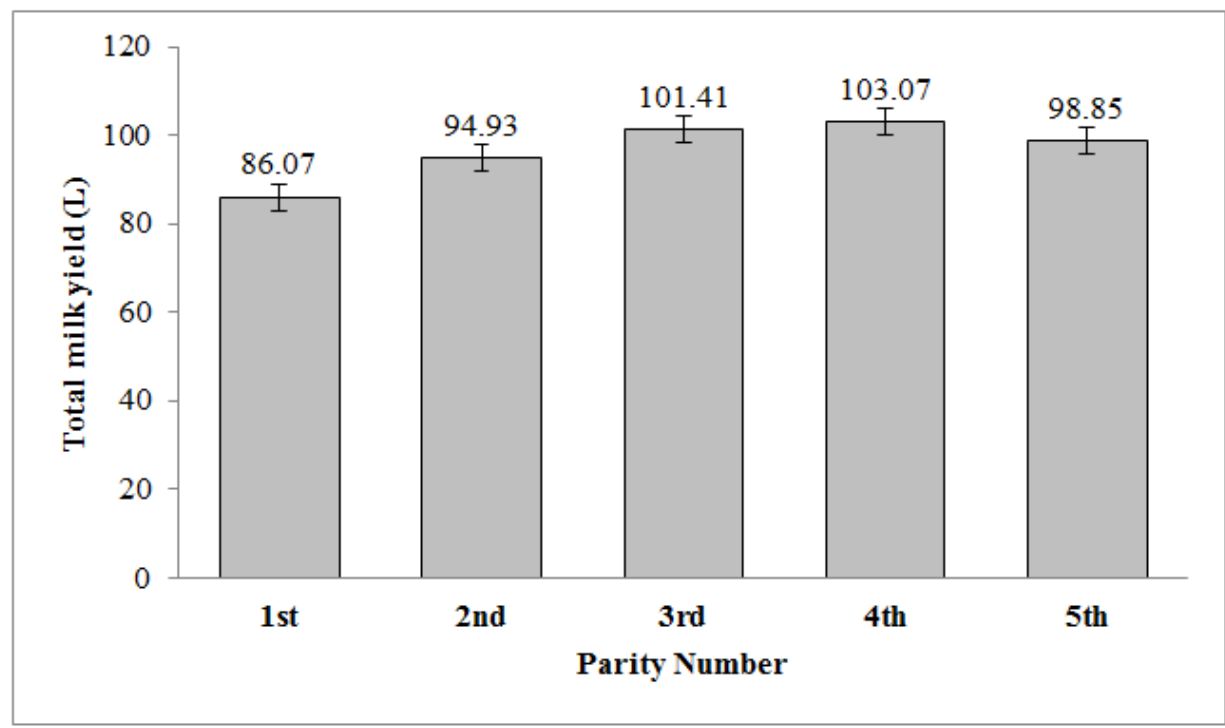

Figure 2. Total milk yield of Sohagi ewes as affected by parity number. 


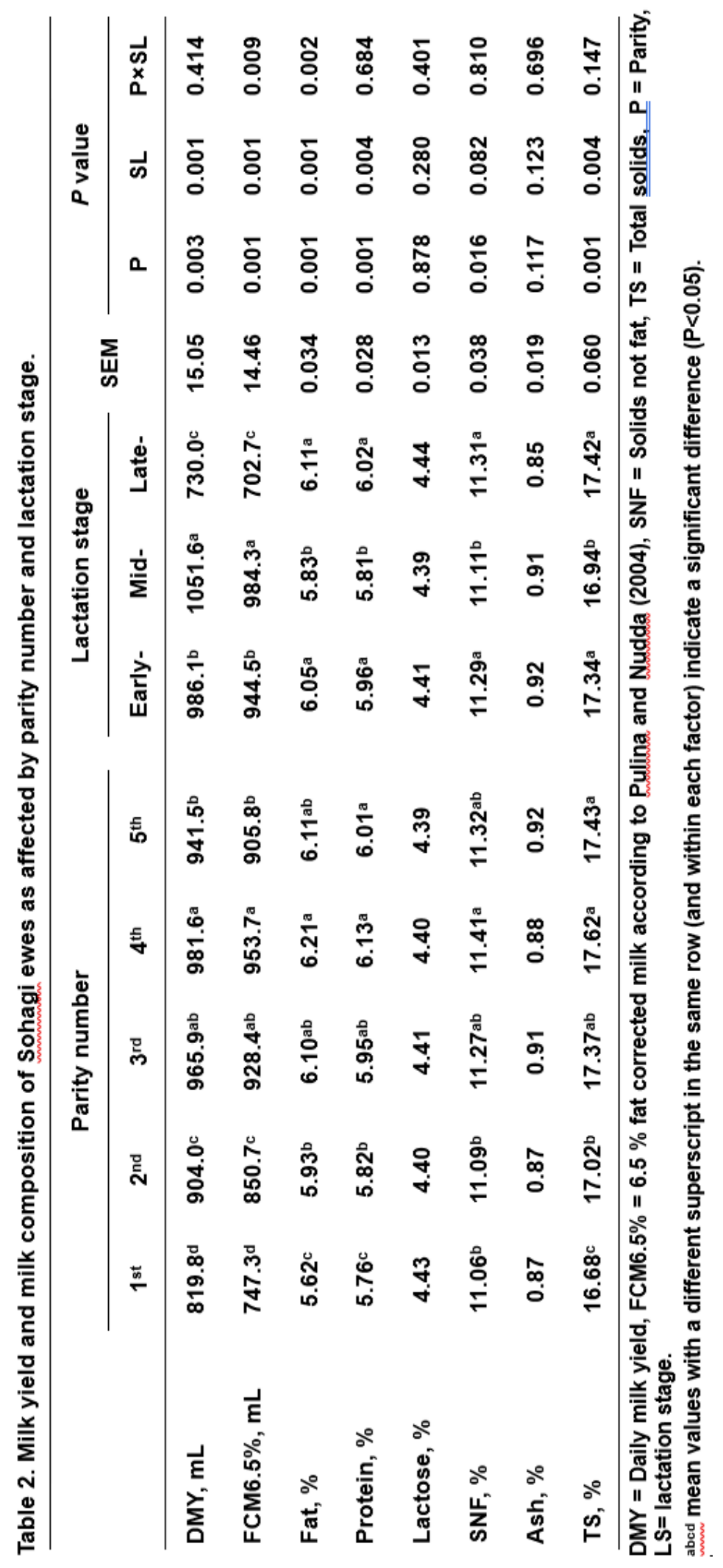


The same results were observed by Pulina et al. (2005), who found that the total milk yield of dairy ewes in the third parity is higher than those of ewes in the first and second parities, and the total milk yield of ewes in the second parity was higher than ewes in the first parity, indicating that total milk yield increased with an increasing parity number. Moreover, Hassan et al. (2018) and Abd Allah et al. (2011) obtained that Rahmaini and Chios ewes at 2.5 - 3.5 years old give relatively higher milk yield than younger or older ones, ewes aged ( $>2$ years old) gave the lowest milk yield followed by those aged ( $>4.5$ years old or more). The same effect was observed by Adegoke et al. (2017) in West African dwarf ewes and suggested that this pattern could be attributed to the continued development of the body and the mammary gland in young animals during the first lactations of ewes. On the contrary, Králíčková et al., (2012) reported that parity number had no significant effect on the daily milk yield of East Friesian ewes.

Table 2 shows that daily milk yield and FCM6.5 \% significantly $(P<0.05)$ were affected by lactation stage, mid-lactation had the highest value (1051.6 and 984.3 $\mathrm{mL}$ ) followed by early- lactation ( 986.1 and $944.5 \mathrm{~mL}$ ) and late- lactation had the lowest values (730 and $702.7 \mathrm{~mL}$ ). This result was in line with Adegoke et al. (2017), who suggested that this pattern could be due to the fact that the body and mammary gland of young animals are still developing during the first part of lactation.

The results revealed that milk contents of fat, protein, SNF, and total solids were increased significantly $(p<0.05)$ with advancing in parity number of ewes until $4^{\text {th }}$ parity, with the $4^{\text {th }}$ parity, milk content of fat, protein, SNF, and total solids reached to highest values compared to milk from ewes with lower parities ( $p<$ 0.05 ) then starts decreasing at $5^{\text {th }}$ parity.
Milk fat, protein, SNF, and total solids values for ewes at $1^{\text {st }}$ and $2^{\text {nd }}$ parities were the lowest $(p<0.05)$ compared to ewes at $3^{\text {rd }}, 4^{\text {th }}$ and $5^{\text {th }}$ parities. Parity number of ewes had no effect $(P>0.05)$ on milk contents of lactose and ash (Table 2).

These results are in agreement with those obtained by Adegoke et al., (2017) who found that parity number of ewe had a significant effect on milk contents of total solids, solid not fat, protein, and fat but not lactose. Milk components were higher in milk produced by ewes in the third parity than in milk produced by ewes in the second and first parities. Furthermore, Sevi et al., (2000) observed the same behavior for milk protein and fat contents, which increased as the number of lactations advanced. They gave two explanations for this behavior. Firstly, the increased body weight of the ewes with a greater number of lactations leads to greater availability of body reserves for the synthesis of milk components. Secondly, the greater development of the udder glandular tissue as the number of lactations rises could also increase milk constituents' synthesis. On the contrary, Abd Allah et al. (2011) reported that the chemical components of milk were not significantly affected by ewe's age, except lower fat percentage $(P<0.05)$ in older ewes compared with that of younger ewes. They suggested that these results may be attributed to the negative association between milk production and fat percentage, where ewes at this age produced higher milk than other groups.

Milk contents of fat, protein, SNF, and total solids were significantly affected ( $P$ $<0.05$ ) by the lactation stage, while the lactose and ash contents were not significantly affected. Milk fat, protein, SNF, and total solids were higher $(P<$ $0.05)$ at early- and late-lactation than at mid-lactation (Table 2).

Findings of Adegoke et al. (2017) on the milk of West African dwarf ewes illustrated that content of total solids, solid not fat, protein and fat were the 
lowest at the $2^{\text {nd }}$ and $3^{\text {rd }}$ week of lactation but increased from the $4^{\text {th }}$ week onward to the highest values at the $12^{\text {th }}$ week of lactation. These trends were also confirmed by Kuchtík et al. (2008) in East Friesian ewes, Kuchtík et al. (2017) in Lacaune ewes, and Williams et al. (2012) in West African dwarf ewes.

The results obtained in the current study for lactose are in line with those found by Sevi et al. (2000) and Adegoke et al. (2017). They reported that lactose is not easy to interpret, and their concentration in milk tends to remain constant,

In the present study, the interaction of $P \times S L$ had a significant effect only on FCM6.5\% and fat content (Table 2). Králíčková et al. (2012) found a significant effect of the interaction of $P \times S L$ on daily milk yield, total solids, and protein contents of East Friesian ewes. On the contrary, Sevi et al. (2000) did not find a significant effect of the interaction of $P \times$ SL on milk yield or milk components of Comisana ewes.

Table 3 shows Pearson correlations among parity number, lactation stage and DMY, FCM6.5\% and milk components of Sohagi ewes' milk. Significant $(P<0.01)$ and positive correlations were found between the parity number and all studied milk characteristics except lactose and ash content. This means that with increasing order of parity also increased DMY, FCM6.5\%, fat, protein, TS, and SNF. Which is consistent with results published by Otherwise, Králíčková et al. (2012) reported that correlations between the parity number and daily milk yield, fat, protein, lactose and total solids were not significant.

On the other hand, there is a negative $(P<0.01)$ correlation between the lactation stage and DMY and FCM6.5\%, which means that DMY and FCM6.5\% decreased with the advancing lactation stage. Only Protein content had a significant $(P<0.05)$ positive correlation with the lactation stage, which is in line with results reported by Sevi et al. (2000). In contrast, Williams et al., (2012) found a positive and high phenotypic correlation between lactation stage and total solids, solid non-fat, fat and protein contents.

\section{Conclusion}

This study revealed that parity number and lactation stage had significant effects on milk yield and milk components of Sohagi ewes. There are positive correlations among these two factors and almost all monitored milk traits Sohagi ewes. Milk of Sohagi ewes in a higher parity might be preferred to ewes in the first and second parities. In addition, milk in early- and late-lactation may be recommended for cheese making due to the high solid content. Finally, the milk production and quality of Sohagi ewes of higher parities have improved, and their use under intensive farm systems will improve the incomes of the breeders. Furthermore, Sohagi ewes may have the potential ability to produce milk, which is suitable for dairy products manufacture, representing a modern approach to improve the value chain for dairy processing in Upper Egypt, which often depends on milk from cows and buffaloes.

Table 3. Pearson correlations between parity, lactation stage, and milk yield and its components.

\begin{tabular}{lcccccccc}
\hline & DMY & $\mathrm{FCM}^{6.5 \%}$ & Fat & Protein & Lactose & TS & SNF & Ash \\
\hline Parity & $\mathbf{0 . 2 8 1}^{* *}$ & $0.383^{* *}$ & $0.490^{* *}$ & $0.393^{* *}$ & -0.088 & $0.462^{* *}$ & $0.298^{* *}$ & 0.170 \\
lactation stage & $-0.647^{* *}$ & $-0.636^{* *}$ & 0.072 & $0.227^{*}$ & 0.087 & 0.138 & 0.154 & -0.155 \\
\hline
\end{tabular}

DMY = Daily milk yield, FCM ${ }^{6.5} \%=6.5 \%$ fat corrected milk according to Pulina and Nudda (2004), SNF = Solids not fat, $\mathrm{TS}=$ Total solids

${ }^{*}$ Correlation is significant at the $\mathbf{0 . 0 5}$ level (2-tailed).

** Correlation is significant at the 0.01 level (2-tailed). 


\section{REFERENCES}

Abd Allah, M., S.F. Abass and F.M. Allam (2011). Factors affecting the milk yield and composition of Rahmani and Chios sheep. International Journal of Livestock Production, 2(3): 24-30.

Abd El Tawab, A.M., A.E. Kholif, M.S.A. Khattab, M.M. Shaaban, F.I. Hadhoud, M.M.M. Mostafa and O.A. Olafadehan (2020). Feed utilization and lactational performance of Barki sheep fed diets containing thyme or celery. Small Ruminant Research, 192, 106249.

Adegoke, E.O., N.S. Machebe, A.G. Ezekwe and O.B. Agaviezor (2017). Effect of parity on changes in udder traits, milk yield and composition of West African dwarf sheep during lactation. Animal Production Science, 57(6): 1047-1057.

Cappio-Borlino, A., B. Portolano, M. Todaro, N.P.P. Macciotta, P. Giaccone and G. Pulina (1997). Lactation curves of Valle del Belice dairy ewes for yields of milk, fat, and protein estimated with test day models. Journal of Dairy Science, 80(11): 3023-3029.

Ebeid, H.M., M.M. Shaaban, R.M.A. Gawad, H.M. Saleh and A.A. Aboamer (2019). Effect of moringa oleifera seed oil as natural feed supplement on the productive performance of lactating ewes. Egyptian Journal of Nutrition and Feeds, 22(2): 273-282.

Elaref, M.Y., H.A.M. Hamdon, U.A. Nayel, A.Z.M. Salem and U.Y. Anele (2020). Influence of dietary supplementation of yeast on milk composition and lactation curve behavior of Sohagi ewes, and the growth performance of their newborn lambs. Small Ruminant Research, 191, 106176.

El-Bassiony, M. F. (2016). Impact of increasing twining rate in Barki ewes on milk yield, milk composition and lambs performance up to weaning. Australian Journal of Basic and
Applied Sciences, 10(18): 365-376.

El-Malky, O.M., T. H. Mostafa, N.H. Ibrahim, F. E. Younis, A. M. Abd El-Salaam and H. A. Tag El-Din (2019). Comparison between productive and reproductive performance of Barki and Ossimi ewes under Egyptian conditions. Egyptian Journal of Sheep \& Goat Sciences, 14(1): 61-82.

Elshazly, A.G. and C.R. Youngs (2019). Feasibility of utilizing advanced reproductive technologies for sheep breeding in Egypt. Part 1. Genetic and nutritional resources. Egyptian Journal of Sheep \& Goat Sciences, 14(1): 39-52.

FAO (2004). FAOSTAT database, Food and Agriculture Organization of the United Nations, Rome, Italy

FAOSTAT (2019). Livestock Primary. Downloaded June 1, 2021 from http://www.fao.org/faostat/en/\#data/QL.

Hassan, H.A., A.A. Abd El-Ghani, S.F. Mohammed, M. Abd-Allah and E.H.A. Hassan (2018). Effects of some medical and aromatic plant seeds on growth performance, milk yield and its composition of Rahmani and Chios sheep. Archives of Agricultural Sciences Journal 1(3): 26-43.

Králíčková, Š., M. Pokorná, J. Kuchtík and R. Filipčík (2012). Effect of parity and stage of lactation on milk yield, composition and quality of organic sheep milk. Acta Universitatis Agriculturae et Silviculturae Mendelianae Brunensis, 60(1): 71-78.

Kuchtík, J., L. Konečná, V. Sýkora, K. Šustová, M. Fajman and I. Kos (2017). Changes of physico-chemical characteristics, somatic cell count and curd quality during lactation and their relationships in Lacaune ewes. Mljekarstvo: časopis za unaprjeđenje proizvodnje i prerade mlijeka, 67(2): 138-145.

Kuchtík, J., K. Šustová, T. Urban and D. Zapletal (2008). Effect of the stage of 
lactation on milk composition, its properties and the quality of rennet curdling in East Friesian ewes. Czech Journal of Animal Science. Sci., 53 (2): 55-63.

Markiewicz-Keszycka, M., G. CzyzakRunowska, P. Lipinska and J. Wojtowski (2013). Fatty acid profile of milk-a review. Bulletin of the Veterinary Institute in Pulawy. 57: 135-139.

NRC (2007). National Research Council. Nutrient requirements of small ruminants. National Academy of Sciences, Washington, DC.

Ouda, S.A.H. and A. Zohry (2016). Management of climate induced drought and water scarcity in Egypt, Springer Briefs in Environmental Science, DOI 10.1007/978-3-319-336602_1

Pulina, G. and A. Nudda (2004). Milk production. In: Pulina, G. (Ed.), Dairy Sheep Nutrition. CABI Publishing

Pulina, G., A. Nudda, N.P.P. Macciotta, G. Battacone, S. Fancellu and C. Patta (2005). Non-nutritional strategies to improve lactation persistency in dairy ewes. In 'Proceedings of the $11^{\text {th }}$ Annual Great Lakes dairy sheep symposium, 3-5 November 2005, Burlington, Vermont, USA, 29-38.

Selvaggi, M., V. Laudadio, C. Dario and V. Tufarelli (2014). Investigating the genetic polymorphism of sheep milk proteins: an useful tool for dairy production. Journal of the Science of Food and Agriculture. 94: 3090- 3099.

Sevi, A., L. Taibi, M. Albenzio, A. Muscio and G. Annicchiarico (2000). Effect of parity on milk yield, composition, somatic cell count, renneting parameters and bacteria counts of Comisana ewes. Small Ruminant Research, 37(1-2): 99-107.

Williams, T.J., I.J. James, M.R. Abdulateef, L.O. Onabegun, S.O. Jinadu, Y.O. Falade, F.T. Solola, O.O. Adewumi and O.E. Oke (2012). Composition and specific gravity of milk of West African Dwarf sheep as affected by stage of lactation and parity. Nigerian Journal of Animal Production, 39(2): 49-56. 


\section{Y. Elaref, et al.,}

تقييم إنتاج وجودة اللبن في النعاج السوهاجي في مواسم الولادة ومراحل الحليب المختلفة تحت نظام الإنتاج المكثف

محمد يوسف العارف(') ، أحمد النحاس محمود(') ، ماجد مروان محمد على(ץ) (') قسم الإنتاج الحيوانى كلية الزراعة - -جامعة سوهاج

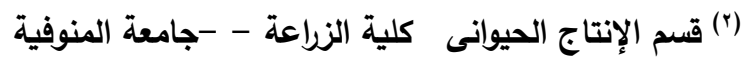

الملخص العربى

أجريت هذه الاراسة لمعرفة تأثير ترتيب موسم الولادة ومرحلة الحلابة على إنتاج اللبن ومكوناته للنعاج السوهاجي. تم

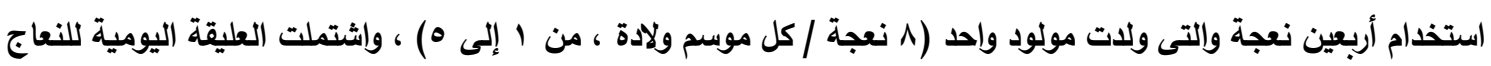

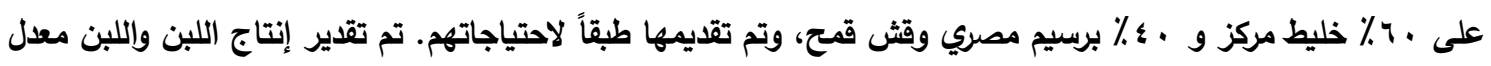

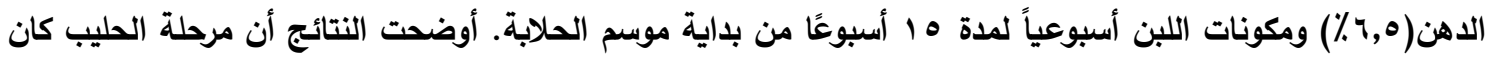
لها تأثير معنوي (P >052) على إنتاج اللبن واللبن معدل الدهن وعلى محتوى الدهون والبروتين والجوامد الصلبة اللادهنية

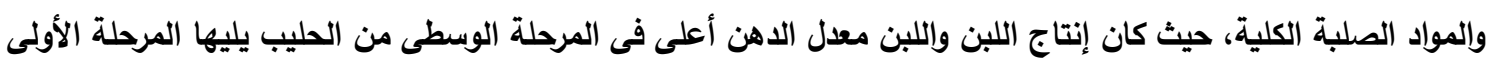

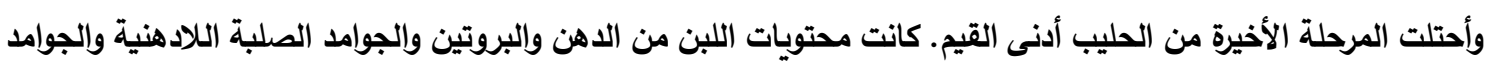
الكلية أعلى (P >05 P المي المرحلتين الأولى والأخيرة من الحليب عنها فى المرحلة الوسطى. زاد إنتاج اللبن وإنتاج اللبن

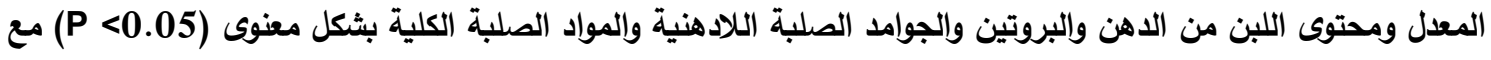

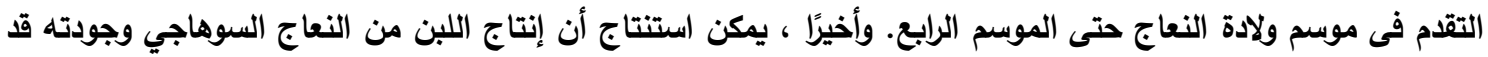

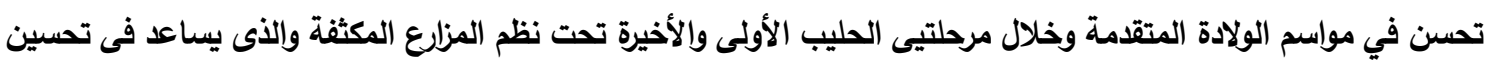

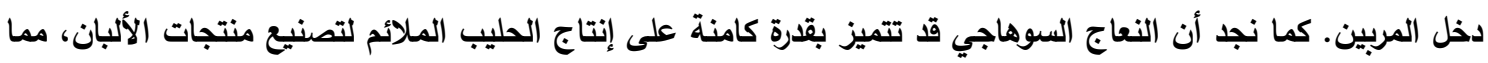
قد يمثل نهجًا حليثًا لتحسين سلسلة القيمة الخاصة بتصنيع الألبان في صعيد مصر، وإلتي غالبًا ما تعتمد على حليب الأبقار 